\title{
The Power of Place in Public Leadership Research and Development
}

\begin{abstract}
Purpose - The purpose of this paper is to foreground place as a critical and central concern for public leadership research, development and practice.

Design/methodology/approach - This invited essay draws on the author's own research and development work engaging in collaborative place-based interventions with academics, policy makers and practitioners.
\end{abstract}

Findings - Place is one of six heuristic lenses in a Leadership Hexad that has been developed to interrogate and better understand leadership in a multi-dimensional manner. Place can also provide an important theoretical and practical fulcrum for bridging both collaborative governance and collective leadership and public and political leadership as well as facilitating cross-sectoral leadership.

Practical implications - This essay argues that more time and effort should be invested into researching and developing place leadership to complement the already extensive efforts to promote collaborative governance and place-based policy initiatives. Place leadership development should be genuinely cross-sectoral in its ambition and should focus on developing emerging and established leaders from the public, private, not-for-profit and indigenous sectors to tackle place-based problems and opportunities.

Originality/value - This essay draws on experience undertaking academic research and conducting leadership development that draws from and feeds into policy and practice. It utilises research from geography, leadership studies, public management, public policy and political science to gain a more sophisticated understanding of the relationship between place and public leadership and how this can be harnessed to improve economic and social impact.

Keywords: Public leadership, Place Leadership, Collaborative Governance, Collective Leadership, Collective Impact and Political Leadership.

An earlier version of this paper was presented as a keynote address at the Fourth International Conference on Public and Political Leadership (PUPOL), given in Wellington on April 11, 2019. 
The Power of Place in Public Leadership Research and Development

Introduction

This article draws on remarks that I made in a keynote address delivered at the Fourth International Conference on Public and Political Leadership (PUPOL) which was held in Wellington in April 2019. PUPOL is an international academic network that aims to contribute to solutions and help societies and their leaders address such challenges through research and scholarship focusing on the role of leaders and leadership in the public and political domains. My address was inspired by the two previous PUPOL keynote addresses: Jean Hartley's address at the Third International PUPOL Conference held in Stockholm in 2018 and Barbara Crosby and John Bryson’s joint address at the Open University in Milton Keynes in 2017. Jean's speech, 'Ten propositions about public leadership' was published in this journal (Hartley, 2018). Barbara and John's speech, 'Why leadership of public leadership matters: and what to do about it' was published in the Public Management Review (Crosby and Bryson, 2018) and was duly given the Best Paper in Public Management award at the International Research Society for Public Management (IPSPM) 2019 conference which was also held in Wellington. Both papers are well worth reading together as their arguments interrelate and complement each other exceptionally well.

Hartley (2018) notes that the practice and the study of public leadership are at a critical juncture. Societies, states and markets around the globe are in a period of profound, transformative change (Benington, 2011). While the volume of research explicitly focusing on public leadership has expanded in recent years (Van Wart, 2013; Ospina, 2016), she compellingly argues in the last, and what I believe to be the most significant of her ten 
propositions, that our research designs have failed to capture the true complexity and dynamism of public leadership challenges. Indeed, she observes that "the context is fastchanging and sensitive antennae are needed to interpret that context and to engage in sensemaking and sense-giving for others, and to understand that others may read the situation, context and challenge very differently" (2018, p. 212).

Crosby and Bryson are similarly concerned with the current focus of public leadership theory and practice which they note is still dominated by highly individualised, heroic 'Great Person' views of leadership and remains seemingly impervious to the enthusiasm of general leadership scholars for more shared, relational and collectivist views of leadership. They argue forcefully that we need to explore a fuller range of leadership theories, "roam more freely through the disciplines" (2018, p. 1265) and to deploy a wider array of research methods.

This paper responds directly to the two inter-related challenges that have been made by Hartley and Crosby and Bryson. In this paper I want to argue that, by actively bringing place into the foreground from the background of our concerns, our research, education and development work will be in a much stronger position to conduct the meaningful sensemaking and sense-giving work that is necessary to capture the true complexity and dynamism of public leadership challenges. In considering the 'What?' of Public Leadership I am considering the complex mix of politicians and public servants working together to deliver civic, political, bureaucratic and administrative leadership ('t Hart, 2014). In considering the 'Why?' of Public Leadership I recognise that this involves “mobilizing individuals, 
organisations and networks to formulate and/or enact purposes, values and actions which aim or claim to create valued outcomes for the public sphere" (Hartley, 2018, p. 203).

The importance of place and place leadership is often acknowledged but rarely becomes a focal point for public leadership researchers who have tended to be more interested in creating generalizable theories that are determinedly not tied to place, indeed they seek to transcend place. By contrast, I am convinced that place is too important a component of leadership to be side-lined in this manner. Moreover, the relationship between place and leadership is a vital relationship that requires urgent attention. As Grint and Holt pithily argue, "Place literally brings the flighty realms of leadership theory down to earth and reminds us that the local nature of change - irrespective of whether this is in private business or local government is quintessentially about what it says on the tin: local. And the local nature of the place matters because it constitutes similar problems differently" (2011, p.97). In actively considering place and purpose in an inter-related manner, we are inevitably forced to consider "what matters" and, in the process, we can provide a more impactful research response to the full suite of societal leadership challenges. The case for a place-based approach to leadership research has been made most persuasively by Greig Guthey and his colleagues who conclude that: "A place-based approach requires scholars to think of organizations not only as strategic enterprises in a global economy, but as buildings and grounds peopled by humans with bodies who live in places and communities that have complex, ecological, social and political histories. A shift towards place-based thinking may lead to scholarly research and management practices that deal more effectively - at local levels - with such thorny issues such as social justice, global climate change, alternative energy and economic inequality to name but a few' (Guthey et al., 2014, p. 62). 
In addition to making our public leadership research more meaningful, foregrounding place will naturally open us up to relational and collective understandings of leadership, recognising that leadership has fundamentally always been a collective process (Jackson and Parry, 2018). As MacLellan notes, "Place is something that can be nurtured and reshaped through individual and collective effort. A place-based approach aims to help address and coordinate the activities of different stakeholders related to initiatives that promote social betterment" (2006, p. 7). With this viewpoint, a place-based approach inevitably opens up critically important and complex governance questions that have to be considered alongside leadership issues (Imperial et al, 2016).

In order to foreground place in our work, we need draw on the broader field of leadership studies in which several scholars have already begun to explicitly examine the nature of the relationship between leadership and place (e.g. Collinge \& Gibney, 2015; Ropo et al, 2015). It is gratifying to note that the theme of the 2019 International Studying Leadership Conference held in Bristol in the UK was "Putting Leadership in its Place". We also need to cast our disciplinary nets wider than the customarily dominant Psychological realm to encompass Anthropology, Economics, Political Science and Sociology and most crucially of all, Geography, which was my first discipline of study. Taking things further, Iszatt-White (2011) has proposed placing context centre-stage in leadership research and, therefore, researching leadership as an inherently contextual performance. Inter alia, she suggests that research based around notions and functions of ethnomethodology will bring to life the sociology of leadership much better than the methods based on psychology that strive for the generalizability of the findings. 
In this article, I will begin by examining the salience and the lingering importance of place to individuals, groups, organisations and communities. I will then describe a conceptual framework for examining leadership that puts place on an equal footing with several more well-established lenses for making sense of and evaluating leadership, namely the person, position performance, process and purpose lenses. The conceptual framework encourages systemic investigation of leadership by interrogating the inter-linkages between each of these six lenses. Bearing this conceptual framework in mind, I will suggest that place-based policy interventions would profitably gain from this stronger sense of the inter-relationship between place and leadership which has recently been described as "Place Leadership". Specially, place can act as a powerful conceptual fulcrum that can be applied to the much needed, closer integration of collaborative governance and collective leadership practices in co-creating public value as well the critical intersection between political and public leadership practices. I will conclude by highlighting several priorities for place leadership research and development as well the benefits and some of the potential pitfalls of bringing a geographic imagination to leadership work.

\section{The Lingering Power of Place}

Place matters to people. It is deeply human to make places, and to think in terms of places. Our hopes, our fears, pain and joys are tied up in places, real or imagined. It is also fundamentally human to develop a sense of belonging to a place, a subjective emotional attachment, in both a positive and a negative way (Collinge and Gibney, 2010). This love of place -- dubbed 'Topophilia' by the eminent Geographer, Yi Fu Tuan -- is not only recognised but also warrants serious study (Tuan, 1990). Place can foster loving attachment 
and it can harness care, enhancement and stewardship. By the same token, places can also encourage greed, prejudice, territoriality and violence. As Wendell Berry notes, "People exploit what they have merely concluded to be of value, but they defend what they love... and to defend what we love we need a particularizing language, for we love what we particularly know" (2001, p. 41).

The renowned Australian author, Kim Mahood, further elaborates on the depth of the relationship people have with place when she observes in her account of returning to returning to the Tanami desert country in far north-western Australia, "this is a kind of a love story. It is an unrequited love story, between a person and a place, and a place doesn't love you back. But perhaps that isn't entirely true. Perhaps it's like loving God, and what you get back is a reflection of what you put in" (Mahood, 2016, p. 2). For indigenous cultures, place is inextricably tied to land (Wolfgram et al., 2016). My PUPOL keynote address was delivered in the Te Heranga Waka Marae at Victoria University of Wellington. When introducing oneself through the customary Mihi at a Marae, the Māori meeting house, one is invited to name both one's maunga (mountain) and the awa (river) that one hails from as well as the waka (canoe) one travelled in, in addition to listing one's tupana (forebears), iwi (tribes) and sub-tribes hapū (sub-tribes). This is a question that initially perplexes those who are new to the Marae but then invariably creates a profound response as it challenges one's view of one self and one's attachment to the world. Indeed it was my engagement with Maori kaumātua (tribal elders) while I worked in Aotearoa (New Zealand) where I developed my appreciation for the powerful relationship between place and leadership, most especially when it is grounded in the land. In particular, Māori tikanga (custom) emphasises the important role that place plays in anchoring ethical and moral leadership practice (Brian Picot Chair in Leadership, 2018; Kelly et al, 2014; Spiller et al, 2015). 
In common with the word, leadership, place has immediate and ready appeal when engaging with citizens. Everyone has a sense of what place and leadership mean and why they are important and significant. In this way, the terms act as double-edged swords. As Creswell notes, "The popularity of place is an opportunity - it is also a problem - place is not a specialised piece of academic terminology. It is a word we use in the English-speaking world. It is a word wrapped in common sense. As we already think we know what it means it is hard to go beyond that common-sense level to understand it in a more developed way" (Cresswell, 2004, p. 3). In trying to make sense of place, Agnew (2011) has helpfully differentated between 'Location' as the term that connotes where the place is spatially; 'Locale', the material setting for social relations to be created in; and 'Sense of Place', the subjective and emotional attachment people have to place. The eminent geographer, Doreen Massey, reminds us that "places are properly depicted as human places--the creations and habitations of human beings--only insofar as they are revealed in settings in which humans act" (1994, p.3). Place is not only rooted in geography but also in history. That is, the interpretations given to space and time.

In the context of an increasingly globalized, inter-connected and mass-mediated world, a broad argument has emerged that place has become increasingly less significant for people and, by implication, for leadership. For example, Anthony Giddens, the accomplished social theorist argues that, "place becomes thoroughly penetrated by dis-embedding mechanisms, which recombine the local activities into time-space relations of ever-widening scope". The net effect is that, "although everyone lives a local life, phenomenological worlds are for the most part global” (Giddens, 1991, p. 146). This is by no means experienced uniformly as 
another prominent social theorist, Manuel Castells (1996), notes in The Rise of the Network Society (1996). He suggests that those who function within the dominant networks are privileged to be a part of the "space of flows" (i.e. global) and their situation contrasts with the excluded, who live in the "space of places" (i.e. local). Along similar lines, in The Road to Somewhere: The Populist Revolt and the Future of Politics, David Goodhart neatly distinguishes between the "anywhere" and the "somewhere" among UK citizens. The former are the metropolitan, well-travelled, better-educated "elite" who tended to vote "Remain" in the Brexit referendum; the latter are "the hardier folk from the provinces" he argues, who have never lost their sense of place or identity, whose "decent" concerns have been ignored and tended to vote 'Leave' in the Brexit referendum (Goodhart, 2017). The significance of place as the basis for leadership within these two groups may be qualitatively different but not necessarily quantitatively different.

While many analysts opine that place is becoming less significant to the economic and social lives of people, there are those who are argue equally persuasively that place is becoming more significant to people and to those who endeavour to lead them. For example, Murray and Overton argue that, "It is indeed true that the world's economies and cultures are increasingly interconnected, and that 'local' forces are penetrating even the most remote and peripheral regions and localities on Earth" (2015, p. 11). However, such processes are articulated and resisted in specific places, complete with particular histories, societies and environments, as they create more uneven geographies. For this reason they conclude that in order to regulate, reform and lead in a globalized world, it is important that "Geography be taken more, not less, seriously" (Murray \& Overton, 2015, p. 11). This is an argument that is echoed by Harm de Blij (2009) in his book, The Power of Place, where he responds angrily to those who blindly subscribe to the "forces of flattening" argument that suggests that place 
is becoming increasingly obsolete, even offensive and deterministic. He insists that a geographic mindset has never mattered more than it does today.

Within the realms of public leadership, Collinge et al (2010) have concluded that despite the radical transformation of society associated with globalisation, shifting patterns of demography and the ongoing revolution in information and communication technologies over the past two decades, "we remain profoundly attached to place in economic, social, cultural and emotional terms. And, so if place matters - then what does it mean for leadership?" (2010, p. 367). The answer from the perspective of extant public leadership research is not much. Reflecting on the growth in interest in place-based policy in the UK in the 2000s, Collinge et al. have disappointingly concluded, "there is no overarching theory of the leadership of place and only relatively limited empirical work done to date" (2010, p. 368). It is to this task that I now turn my attention to.

The Inter-Relationship between Place and Leadership

To date, it is context rather than place that has garnered most attention by leadership scholars. The need to properly recognise and theorise context in leadership studies was first raised by Osborn et al (2002). Porter and McLaughlin (2006) have likened the role of context in leadership to the weather, it's always there but hard to separate out when trying to make sense of a situation. A Special issue of Human Relations devoted to examining the role of context in leadership studies concluded that: "despite the encouraging trend of increased attention being placed on the context in leadership research, the vast majority of this research has focused on the influence of context on leadership or relationships between leadership and 
both individual and organizational outcomes" (Liden and Antonakis, 2009, pp. 1596-7).

Relatively neglected, has been the influence that individuals may have upon on the context.

How then should we seek to understand the relationship between leadership and place? To begin with, it is useful to think of the connection between leadership and place as an interdependent relationship which can be forged by both leaders and followers for responsible or irresponsible purposes. When and where you are located partially shapes how you might lead and follow, why you might lead and follow and who you might lead and follow. Similarly, from the perspective of leadership practice, we can usefully think of leadership as both an enabler and a constraint. It provides a powerful strategic resource as the basis for forging a common identity, purpose and direction. It can also significantly hinder or clamp leadership initiatives.

It is these types of question that led my late colleague, Ken Parry and I, to revise our definition of leadership to actively foreground place rather than the more generic concept of context. Our revised definition conceptualised Leadership as "an interactive process involving leading and following within a distinctive place to create a mutually important identity, purpose and direction" (Jackson \& Parry, 2018, p. 12). In this definition, we envisage leadership as being primarily a communicative process that is always constantly evolving and becoming (Carroll et al., 2008; Crevani, Lindgren, \& Packendorff, 2007). Leadership has to be collectively and consciously created (Ospina \& Uhl-Bien, 2012) partially through intentional leadership development practices. Leadership is not something that is attained and then merely maintained, it is always in flux and subject to contestation (Fairhurst, 2007). 
Grint (2005) suggests that leadership has traditionally been understood in four quite different ways: Leadership as Person, Leadership as Results, Leadership as Position, and Leadership as Process. Guided by our definition of leadership, we have added two new lenses: Place and Purpose to this heuristic framework, to foreground the context in which leadership is enacted as well as the reason why leadership is enacted. This enhanced leadership framework, therefore, incorporates six lenses of leadership: Position, Person, Performance, Process, Place, and Purpose. Each of these lens poses a critical question for leadership researchers and developers to answer in a manner akin to the well-worn "Five W's and a H" technique that journalists use for writing the complete story. These are briefly described below in the Leadership Lens Hexad which also highlights the need to examine how each of these lenses can be inter-connected in a way that provides a multi-dimensional understanding of leadership that has been inspired by Kenneth Burke's Dramatistic Pentad (Burke, 1945; Souza and Jackson, 2018).

(Insert Figure 1 Here)

Conceptually, the lenses are positioned in the framework in a way that reflects how leadership has been approached by different leadership theories, from more traditional perspectives (i.e. Position, Person, and Performance) that link leadership to formal positions of authority, charismatic presence and/or the results achieved by the leaders at the top of the Hexad, to a more processural and relational emphasis of leadership which is enacted through social interactions (i.e. Process), to a more recent concern with purposeful leadership (i.e. Purpose) as leadership scholars are actively engaging in a 'responsible leadership' research, 
education and development agenda (e.g. Maak \& Pless, 2006; Kempster \& Carroll, 2016), through to a place-based leadership (i.e. Place).

The Hexad highlights the inter-relationships between the six lenses of leadership. While applying each of the six lenses of leadership can yield important insights regarding the creation of leadership, it is through the analysis of the inter-linked lenses that the full heuristic power of this leadership framework can be demonstrated (Souza and Jackson, 2019). These inter-linkages introduce additional questions about leadership that are not as obvious and are sometimes over-looked. For example, how does the place of leadership influence the purpose of leadership? In turn, how does the purpose of leadership influence its place? These inter-linkages are inherently dialogic: they are best viewed in conversation with each other, most especially when confronting a problem, in this case the creation of leadership. As with all conceptual frameworks, the Leadership Hexad is best understood in its practical application. In the following section I will provide a brief overview of how place has been utilized as the basis for policy initiatives aimed at addressing economic and social agenda and argue how these initiatives could be strengthened with a fuller appreciation of the inter-dependent relationship that exists between place and leadership.

The Emergence of Place Leadership

Place-shaping policy became a central plank of policy in the UK in the first part of the millennium, spearheaded by Michael Lyons (Lyons, 2007). This decentralizing policy thrust gave place leadership some prominence and momentum through the work of a small but energetic group of inter-disciplinary researchers (Benington \& Turbitt, 2007; Collinge et al, 2010; Gibney et al, 2009; Grint, 2010; Mabey and Freeman, 2010). The emphasis on place 
was stimulated by a new urban competiveness agenda, the emergence of the knowledgebased economy and the necessities of “joined-up" government' (Gibney et al, 2009). While this went some way to putting place on the map of leadership studies, the place leadership work stalled due to a far-ranging political shift to more centralised policy imperatives brought on by a change in government (Grint \& Holt, 2011).

In Australia, place-based initiatives (PBIs) have similarly ebbed and flowed with political cycles. PBIs are "programs designed and delivered with the intention of targeting a specific geographical location(s) and particular population groups in order to respond to complex social problems" (Wilks et al., 2016). PBIs typically focus on areas of and communities with entrenched disadvantage or deprivation. They incorporate and attempt to actively integrate health, education, child development, family well-being, housing, urban regeneration, crime reduction, employment, economic development, indigenous communities, immigrant communities, social inclusion and social exclusion.

The potential advantages of place-based policy initiatives (Tiernan, 2016; Hambleton and Howard, 2013; Leech and Worrall, 2018; Taylor and Buckly, 2016; Wilks et al., 2016) can be summarised as follows: they enable the prospect of better targetted interventions based on evidence; they create the potential for communities to have a greater say in service provision and issue identification (powerfully distilled in the slogan, "Nothing about us without us"); and they can help to foster innovation in service delivery which may or may not lead to less public fund expenditure. In creating these outcomes, there is a general aspiration that PBIs might lead to improved social cohesion and resilience which, in the longer term, might lead 
to improved trust in government, something which most Western democracies are becoming increasingly concerned with.

While the advantages of place-based initiatives are generally well recognised, the disadvantages also need also to be recognisd and considered (Tiernan, 2016; Hambleton and Howard, 2013; Leech and Worrall, 2018; Taylor and Buckly, 2016; Wilks et al., 2016). First, there is the potential for duplication of effort and inefficient allocation of resources. Second, PBIs should not be launched to create an immediate response to a crisis to satisfy media pressure. Third, PBIs can be derailed by inadequate or confused inter-governmental coordination between central, state and local governments. Fourth, there is a temptation to address this problem by adding an extra layer of governance which can ultimately lead to dissipated effort, resources and support. Fifth, while it is relatively straightforward to launch PBIs it is considerably more taxing to create an effective transition from the PBI to a new but different "business as usual" situation. Finally, there is the reverse "Nimby" syndrome in which regions, cities and regions feel aggrieved because that have not been the focus of a PBI.

Despite considerable efforts and investment in program monitoring and evaluation, PBIs have yet to demonstrate their impact in a fully convincing and unqualified manner. Indeed, there is a growing recognition that, "traditional top-down, often-siloed approaches to social policy have been unable to create and sustain large-scale change" (Tiernan, 2016, p.7). In an effort to address some of the shortcomings of previous PBIs, a new generation of place-based policy interventions have been developed that are anchored in a "Collective Impact Model" (CIM). The CIM "seeks to overcome these and other shortcomings of previous approaches by 
bringing together stakeholders from multiple sectors under common goals with a common information base and measuring tools to tackle big social problem” (Tiernan, 2016, p. 7).

In November 2018, I had the good fortune to join over 500 people gathered in the City of Logan in Queensland, the home of Logan Together, Australia's most widely recognised place-based initiative that utilises a CIM, to celebrate place-based change efforts to date and to look ahead. This gathering produced the "ChangeFest 2018 Manifesto" which called upon political leaders, community organisations, philanthropists, businesses and others to make a "long-term, transparent investment in Australia by empowering communities to provide a better future for their children" (ChangeFest, 2018). The Call to Action identified five priorities: invest in community leaders and action; change the system at all levels of government; create accountability and support across all stakeholders; establish an independent evidence program to inform the way ahead and reward community-led, early years efforts. Placing place leadership development first on this list of actions was no accident, it was a theme that recurred in most of the sessions as did the need to ensure that Aboriginal and Torres Strait Islander People were empowered and enabled to be at the forefront of all system change design and delivery.

The important role that leadership plays in determining the success or failure of place-based initiatives has only recently been given due recognition by scholars. As Sotarauta and Beer note, "the increasing interest in place leadership represents a growing recognition of the need to reinsert questions of agency in accounts of regional performance, as attention has focused almost exclusively on structural factors at the expense of understanding the human drives of change” (2017, p. 211). I have noted in my general interactions with public servants that 
"questions of agency" are generally given lip service to but are quickly pushed aside by a pervasive pre-occupation with policy protocols and governance frameworks. In this regard they tend to be governance-heavy and leadership-light. The opposite is true in my engagement with community organisation leaders who tend to be leadership-heavy and governance-light.

In advancing the increased prominence that is being given to place leadership in place-based initiatives, Sotarauta et al (2017) note that, first and foremost, place leadership recognises the salience of fragmented or shared actions, among a whole series of organisations and/or several leaders rather than top-down intra-organisational leadership processes. As such, it shares the fundamental assumption that underpins collective leadership. Collective leadership represents an emerging theoretical umbrella that captures diverse scholarship on the relational (e.g. shared, distributed, integrative, etc.) aspects of leadership (e.g. Bryman et al., 2011; Huxham \& Vangen, 2000; Ospina, 2017; Uhl-Bien and Ospina, 2012; Vangen \& Huxham, 2003; Yammarino et al., 2012). Viewed this way, place leadership can further assist public management scholars to continue to develop the view of public leadership as a collective, multilevel, cross-sector endeavour imbued with public values that provides a compelling bulwark against the highly individualised, autocratic solutions promulgated by populists and "thinly masked demagogues" (Crosby and Bryson, 2018).

Second, Sotaurata and Beer (2017) observe that place leadership involves processes where not all nominal leaders are formally recognised as place leaders. Indeed, it is frequently the case that formal leaders may exert relatively little effective place leadership. Some of the most effective place leadership is instead exerted by low-profile, non-elected citizens through 
informal and referent power and by the sheer weight of numbers of their followers. Place leadership has resulted in a growing recognition that public value is inherently co-created not only by government, but also by other sectors, organizations and actors and by governmentcitizens relations (Crosby, 't Hart \& Torfing, 2017; Bryson et al., 2017; Page et al., 2015; Vangen, Hayes \& Cornforth, 2015). By the same token, it would be wrong and misleading to underestimate the importance of political leaders in creating sustainable place leadership. This view would indeed be counter to PUPOL's mission which is to highlight the interconnections between public and political leadership which are often separated due to wellestablished disciplinary demarcation lines, most notably between public administration and political science. To this end, Crosby and Bryson (2018) highlight the importance of "interactive political leadership" in place leadership which focuses on the ways that elected and appointed officials work directly with citizens to jointly tackle problems and promote innovation while preserving the officials' special responsibility for leading and managing public institutions and democratic process.

Moreover, the political context has an important bearing on enabling and constraining the creation and practice of place leadership. For example, in comparing and contrasting place leadership in Australia and Finland, Sotarauta and Beer (2017) conclude that place leadership in Australia tends to have a greater dependency on the voluntary efforts of individuals from the private sector and the broader community. Its relationship with government tends to be indirect and is marked by a tension between the centralising tendency of central governments and the need for independently-minded local leaders to engage to secure resources. This tension was especially evident in many of the forums at the ChangeFest event that I referred to earlier. Place leadership in Finland, on the other hand, is institutionally based in the context of a balanced governance system where there is a greater level of systemization, a 
stronger involvement by the public sector and a well-developed knowledge base and a more technocratic perspective" (2017, p. 221). It should also be noted that the national contexts for place leadership are also in flux. For example, Bowden and Liddle (2018) have detected a shift in approach taken by public servants in the UK to place-based partnerships over the past two decades away from a controlling approach to a more influencing approach.

Third, place leadership recognises the importance of multi-scalar, dynamic and interactive governance processes between national, local and regional government actors, firms, universities, research institutions, public and/or semi-public development agencies (Crosby and Bryson, 2005; Beer and Sotaurata, 2017; Budd and Sancino, 2016; Hambleton, 2015). In this regard, it provides an important bridge to the concept of Collaborative Governance which refers to the governing arrangement that engage citizens and non-governmental actors into public value co-creation assemblies across public policy making and implementation processes (Ansell \& Gash, 2008). Emerson et al (2012) take an even boarder view of Collaborative Governance when they suggest that it should encompass, "the processes and structures of public policy decision-making and management that engage people constructively across the boundaries of public agencies, levels of government, and/or the public, private and civic spheres in order to carry out public purpose that could not otherwise be accomplished" (2012, p.2).

The role of place became the central concern of a panel that I was part of organising for the 2018 International Research Society on Public Management (IRSPM) annual conference on "Leadership and strategic planning for places and spaces". Many of the empirical papers that were presented in this panel pointed to a critical gap in our understanding of the interrelationship between collaborative governance and collective leadership practices that became 
readily apparent in many place-based initiatives. This gap became the spur for our IRSPM 2019 panel on "Collective leadership and collaborative governance for public value cocreation". For 2020, our panel focus will be on "Conducting public leadership that matters: Valuing research processes, methods and outcomes". One of the more interesting and important questions that our recent pre-occupation with place leadership has thrown up has been memorably encapsulated by Maarku Sotaurata in his book, Leadership in the City, which is "Where does governance end and leadership begin?" (Sotarauta, 2016, p. 3). This is a question which is considered all too rarely but one that should become an important consideration not only for public leadership scholars (Imperial et al, 2016) but for leadership and governance scholars in general (Cikaliuk et al., 2019).

\section{Conclusion}

In this article I have argued that, as place continues to fundamentally matter to people, either as citizens, consumers or community members, it is surprising and somewhat concerning that place and its relationship to leadership, has received little attention either theoretically or empirically by public leadership scholars. I have suggested that place can act as an important strategic resource for leadership in building collective identity, purpose and strategy. It can also provide a significant constraint. Places also provide important bases for political, economic, social and organizational action at a wide variety of scales from the individual organisation such as a school, to a neighbourhood, a suburb, a city, a region, a nation and a distinctive part of the world. Places can transcend personality- or positionally-driven leadership to focus on longer-term and more enduring purposes that are multi-generational. 
Following on from this, I noted the recent growth in interest in place leadership, that is leadership in, of and over places as a key determinant of public value (co)creation and/or (co)destruction. A place leadership perspective can shed more light on both the practices of collective leadership and the arenas/spheres of collaborative governance that can enact public value co-creation. Place leadership highlights the role of urban and rural areas in public value co-creation to deal with wicked and/or societal challenges. It also emphasises how better integrated public and political leadership can engage members of society in interactive policy and public management processes that can result in the co-creation of public value through new arenas such as living labs, collaborative platforms, and participatory processes both online and in real places gather together actors and/or citizens into public value cocreation.

With all of this in mind, I have argued that place leadership can and should no longer be sidelined by public leadership researchers. Instead, it must be foregrounded as a primary concern of public leadership scholars in their research, education and development work. The Leadership Lens Hexad that I have briefly described might provide a potentially useful conceptual starting point for both researching and teaching the multi-faceted relationship between leadership and place. In order to gain the rich and deeply nuanced understanding of place we will need to draw on a wider range of disciplinary perspectives than we might not be customarily familiar with but have traditionally made important contributors to the understanding of place. These would obviously include the social sciences such as Economics, Political Science and Sociology and most crucially of all, Geography. It would also encompass various disciplines within the Humanities such as Anthropology, History, Linguistics, Philosophy, Religious Studies and the Visual and Performing Arts. In doing this, place leadership might serve to accelerate the long discussed and promised but rarely 
actualised inter-disciplinary thrust for leadership studies in research and teaching pursuits (Jackson et al, 2019). Along these lines, I have long held a desire to see a fully-developed 'Geography of Leadership' being introduced into our leadership education curriculum and had the privilege of teaching a postgraduate course with this title with my colleague, Eric Guthey, from the Copenhagen Business School. We were struck by the general lack of geographic understanding and imagination shown by the students but were pleased to observe a genuine curiosity to learn how this might enrich their business studies.

Another key task moving forward is to find novel and sustainable ways to develop place leadership capability and capacity (Worrall, 2015; Worrall and Jackson, 2017; Worrall and Kjaerulf, 2019). Leadership development has traditionally been the preserve of organisations (Day, 2011; Jung, Harrow and Phillips, 2013). Within government, however, there has been a shift towards developing leadership across the public service sometimes utilising joined-up, multi-agency leadership development programmes and initiatives. Taking a place-based focus on leadership development broadens the range of these partnerships (Bowden and Liddle, 2017). The focus is on developing leadership rather than leaders and primary importance is placed on engendering collaboration, power and trust in the formation of horizontally-based leadership coalitions that are anchored in meaningful way with specific places. My experience in New Zealand suggests that these programs work most effectively with emergent leaders from business, government, NGO and indigenous sectors who work on important place-based problems over a 12-18 month period. The long-term benefits benefits notwithstanding, Beer and Clower (2014) note, place leadership development comes at a cost. Regions, cities and communities need to have sufficient 'slack resources' to ensure successful leadership development. It is not sufficient to rely on an economic shock or crisis to guarantee the emergence of new, more effective forms of place leadership. Moreover, there 
are significant gaps in leadership in some nations. Those with more centralised systems of government are likely to experience local leadership deficits and so considerable time effort and investment in place development will be required (Sansom, 2019).

In closing this article in which I have enthusiastically championed the cause of place leadership, it is important to add a cautionary note. While place can provide a fundamentally satisfying, humane, and responsible way to approach larger questions of environmental prudence and social justice, we should be fully aware that "place is difficult to theorize because of its confused and intractable qualities. It also arouses suspicions because it is undeniably associated with exclusion and xenophobia" (Light and Smith, 1998, p. 6). A preoccupation with place not only raises all manner of ontological and epistemological complexity, it also brings to the fore profound ethical and moral concerns which require due consideration. It is, therefore, important as well as prudent to recognise that place should always be considered "an incorrigible philosophical problem", if only because it so fundamentally structures human experience. With these important caveats in mind, I invite you to bring place to the fore of your research, teaching and practice of public leadership.

\section{References}

Agnew, J. (2011), "Space and Place”, in J. Agnew and D. Livingstone (Eds), Handbook of Geographical Knowledge, London: Sage.

Ansell, C. and Gash, A., 2008. Collaborative governance in theory and practice. Journal of Public Administration Research and Theory, Vol. 18, No. 4, pp.543-571.

Beer, A. and Clower, T. (2014), "Mobilizing leadership in cities and regions", Regional Studies, Vol. 48 No. 1, pp. 5-20. 
Benington J (Ed) (2011), New Horizons for Local Governance, Local Authorities and Research Councils Initiative (LARCI): London.

Benington, J. and Turbitt, I. (2007), "Adaptive leadership and the policing of the Drumcree demonstrations in Northern Ireland”, Leadership, Vol. 3 No. 4, pp. 371-395.

Berry, Wendel (2001) In the Presence of Fear: Three Essays for a Changed World, Orion: Great Barrington, MA

Bowden, A. and Liddle, J. (2018), "Evolving public sector in the leadership of place-based partnerships: From controlling to influencing policy?", Regional Studies, Vol. 52 No. 1, pp. 145-155.

Brian Picot Chair in Ethical Leadership (2018), Ethical Leadership: Opportunities and Challenges for Aotearoa New Zealand. New Zealand: Victoria University of Wellington. pp.49. (www.victoria.ac.nz/ethical-new-zealand).

Budd, L. and Sancino, A. (2016), "A Framework for city leadership in multilevel governance settings: the comparative contexts of Italy and the UK", Regional Studies, Regional Science, Vol. 3 No. 1, pp. 129-145.

Burke, K. (1945), A Grammar of Motives, University of California Press, Berkeley, CA.

Carroll, B., Levy, L. and Richmond, D. (2008), "Leadership as practice: Challenging the competency paradigm”, Leadership, Vol. 4 No. 4, pp. 363-79

Castells, M. (1996) The Rise of the Network Society: The Information Age: Economy, Society and Culture Vol. I, Blackwell, Cambridge, MA;

ChangeFest 2018, (2018), "ChangeFest Manifesto" (https://logantogether.org.au/wpcontent/uploads/2018/11/Final-ChangeFest-Policy-Statement-presented-CF-22-Nov.pdf

Cikaliuk, M., Erakovic, L., Jackson, B., Noonan, C. and Watson, S. (2019), The Board as the Nexus of Leadership and Governance, Cambridge University Press, Cambridge.

Collinge, C., Gibney, J. and Mabey, C. (2010), "Leadership and place”, Policy Studies, Vol. 31 No. 4, pp.367-378.

Cresswell, T. (2004) Place: A Short Introduction, Oxford: Blackwell

Crevani, L., Lindgren, M., and Packendorff, J. (2007), "Shared leadership: A post-heroic perspective on leadership as a collective construction", International Journal of Leadership Studies, Vol. 3 No. 1, pp. 40-67.

Crosby, B. and Bryson, J. (2005), “A leadership framework for cross-sector collaboration”, Public Management Review, Vol. 2 No. 2, pp. 177-201.

Crosby, B. and Bryson, J. (2018), "Why leadership of public leadership research matters: and what to do about it", Public Management Review, Vol. 20 No. 9, pp. 1265-1286. 
Crosby, B.C., 't Hart, P. and Torfing, J., (2017), "Public value creation through collaborative innovation", Public Management Review, Vol. 19 No. 5, pp.655-669.

Day, D. (2011), "Leadership development", in Bryman, A., Collinson, D, Grint, K, Jackson, B. and Uhl-Bien, M. (Eds), Sage Handbook of Leadership. Sage, London, pp. 37-50.

De Blij, H. (2009), The Power of Place, Oxford University Press, Oxford.

Emerson, K., Nabatchi, T. and Balogh, S., (2012), "An integrative framework for collaborative governance', Journal of Public Administration Research and Theory, Vol. 22 No. 1, pp.1-29.

Fairhurst, G. T. (2007) Discursive leadership: In conversation with leadership psychology. Sage, Thousand Oaks, CA.

Gibney, J. and Collinge, C. (2015). Leadership and Place, Routledge, London.

Gibney, J., Copeland, S. and Murie, A. (2009) "Toward a `New' Strategic Leadership of Place for the Knowledge-based Economy”, Leadership, Vol 5 No.1, pp. 5-23.

Giddens, A. (1991), Modernity and Self-Identity' Stanford University Press: Stanford, CA..

Goodhart, P. (2017), The Road to Somewhere: The Populist Revolt and the Future of Politics, Hurst, London.

Grint, K. (2005), Leadership: Limits and Possibilities, Palgrave Macmillan: Basingstoke.

Grint, K. (2010), “Foreword: Placing leadership”, Policy Studies, Vol. 31 No. 4, pp. 365-366.

Grint, K., and Holt, C. (2011), "Leading Questions: If 'Total Place, 'Big Society' and local leadership are the answers: What's the question?', Leadership, Vol. 7 No. 1, pp. 85-98.

Guthey, G.T., Whiteman, G., Elmes, M., (2014), "Place and sense of place: Implications for organizational studies of sustainability”, Journal of Management Inquiry, Vol. 23 No. 3, pp. 254-265.

Hambleton, R. (2015), Leading the Inclusive City. Place-based Innovation for a Bounded Planet, Policy Press: Bristol.

Hambleton, R. and Howard, J. (2013), "Place based leadership and public service innovation”, Local Government Studies, Vol. 39 No.1, pp. 1-24.

Hartley, J. (2018), “Ten propositions about public leadership", International Journal of Public Leadership, Vol. 14 No. 4, pp. 202-217.

Huxham, C. and Vangen, S. (2005), Managing to Collaborate: The Theory and Practice of Collaborative Advantage, Routledge: Abingdon. 
Huxham, C., \& Vangen, S. (2000), "Leadership in the shaping and implementation of collaboration agendas: How things happen in a (not quite) joined-up world", Academy of Management journal, Vol. 43 No. 6, pp. 1159-1175.

Imperial, M., Ospina, S., Johnston, E., O’Leary, R., Thomsen, J., Williams, P. and Johnson, S. (2016), "Understanding leadership in a world of shared problems: Advancing network governance in large landscape conservation", Frontiers in Ecology, Vol. 14 No. 3, pp. 126-134.

Iszatt-White, M. (2011), "Methodological crises and contextual solutions: An ethnomethodologically informed approach to understanding leadership", Leadership, Vol. 7 No. 2, pp. 119-135.

Jackson, B. and Parry, K. (2018), A Very Short Fairly Interesting and Reasonably Cheap Book About Studying Leadership, Sage: London.

Jackson, B., Kempster, S. \& Fulop, L. (2019), “'Take Your Lead': In Search of Very Short, Fairly Interesting, and Reasonably Impactful Contributions to the Future of Leadership Studies", Journal of Management and Organization, Vol. 25 No. 3, pp. 355-363.

Jung, T., Harrow, J. and Phillips, S. (2013), "Developing a better understanding of community foundations in the UK's localisms", Policy and Politics, Vo;. 41 No. 3, pp. 409-427.

Kelly, D., Jackson, B. \& Henare. M. (2013), "He Apiti Hono, He Tātai Hono: Ancestral leadership, cyclical learning and the eternal continuity of leadership", in Jack, G. \& Westwood, R. (Eds), Core-Periphery Relations and Organisation Studies, Palgrave Macmillan, Hants., UK, pp. 164-184.

Kempster, S. and Carroll, B. (eds), (2016) Responsible Leadership: Realism and Romanticism, Routledge, Abingdon, OXON.

Leech, D. \& Worrall, R. (2018), "Place-based leadership: Both opportunity and challenge", National Health Executive Newsletter, March/April.

Liden, R.C. and Antonakis, J. (2009), "Considering context in psychological leadership research”, Human Relations, Vol. 62 No. 11, pp. 587-605.

Light, A. and Smith, J.M. (1998) Philosophy and Geography II: The Production of Public Space, Rowan and Littlefield, New York.

Lyons, M. (2007), Place shaping: A shared ambition for the future of local government final report, The Stationery Office: London.

Maak, T., and N. M. Pless. (2006), Responsible Leadership, Routledge, London.

Mabey, C. and Freeman, T. (2010), "Reflections on leadership and place", Policy Studies, Vol. 31 No. 4, pp. 505-522. 
MacLellan, D. (2006), "Exploring A Place-based Approach for Civic Engagement", Paper Presented to the Canadian Political Science Association.

Mahood, K. (2016), Position Doubtful: Mapping Landscapes and Memories, Scribe Publications, Brunswick, VIC.

Massey, D. (1994), Space, Place and Gender, University of Minnesota Press, Minneapolis, MN.

Murray, W. and Overton, J. (2015), Geographies of Globalization, Routledge, London.

Osborn, R., Hunt, J. and Jauch, L. (2002), "Toward a contextual theory of leadership", Leadership Quarterly, Vol. 13 No. 6, pp. 797-837.

Ospina, S. (2016), "Collective leadership and context in public administration: Bridging public leadership research and leadership studies," Public Administration Review, Vol. No. 2, pp. 275-287.

Page, S., Stone, M., Bryson, J. \& Crosby, B. (2015), "Public Value Creation by Cross-Sector Collaborations: A Framework and Challenges of Assessment", Public

Administration, Vol. 93 No. 3, pp.715-732.

Paul ‘t Hart, P. (2014), Understanding Public Leadership, Palgrave Macmillan, Basingstoke.

Porter, L., \& McLaughlin, G. (2006), "Leadership and the organizational context: Like the weather', Leadership Quarterly, Vol. 17, pp. 559-576.

Ropo, A., Salovaara, P., Sauer, E. and De Paoli, D., (2015), Leadership in Spaces and Places, Edward Elgar, Cheltenham, UK.

Sansom, G. (2019), “Is Australian government ready for localism?", Policy Quarterly, Vol. 15 No. 2, pp. 25-32.

Sotarauta, M. and Beer, A. (2017), "Governance, agency and place leadership: Lessons from a cross-national analysis”, Regional Studies, Vol. 51, No. 2, pp. 210-223.

Sotarauta, M., Beer, A. \& Gibney, J. (2017), "Making sense of leadership in urban and regional development”, Regional Studies, Vol 51, No. 2, pp. 187-193.

Souza, R. and Jackson, B. (2019), "Enacting leadership in the favela: An empirical investigation using a dialogical heuristic instrument", in Koonce, R. and van Loon, R. (Eds), The Dialogic Challenge of Leadership Development, Information Age Publishing, Charlotte, NZ, pp. 99-127.

Spiller, C., Barklay-Kerr, H \& Panoho, J. (2015), Wayfinding Leadership: Ground-breaking Wisdom for Developing Leaders, Huia, Wellington,NZ.

Taylor, M. and Buckly, E. (2016), "Historical review of place-based approaches", Institute of Voluntary Action Research (IVAR): London. 
Tiernan, A. (2016), 'Collaboration in Place', 2016 Solomon Lecture, Policy Innovation Hub, The Machinery of Government (https: medium.com/the machinery-ofgovernment/collaboration-in-place).

Tuan, Yi-Fu. (1974), Topophilia, Prentice-Hall, Englewood-Cliffs, CA..

Uhl-Bien, M., \& Ospina, S. (Eds.) (2012), Advancing Relational Leadership Research: A Dialogue Among Perspectives, Information Age Publishing, Greenwich, CT.

Van Wart, M. (2013), “Administrative leadership theory: a reassessment after 10 years", Public Administration, Vol. 91 No. 3, pp. 521-543.

Vangen, S., \& Huxham, C. (2003), "Enacting leadership for collaborative advantage: Dilemmas of ideology and pragmatism in the activities of partnership managers", British Journal of Management, Vol. 14, pp. S61-S76.

Vangen, S., Hayes, J. P., \& Cornforth, C. (2015), "Governing cross-sector, interorganizational collaborations", Public Management Review, Vol. 17 No. 9, pp. 12371260.

Wilks, S., Lahausse, J. \& Edwards, B. (2015), “Commonwealth place-based service delivery initiatives: Key learnings project” (Research Report No 32), Australian Institute of Family Studies, Melbourne.

Worrall, R and Jackson, B. (2017), "Whose place is it any way?: Using leadership development to traverse regional fault lines", Paper presented at the Regional Studies Winter 2017 Conference, November 16-17

Worrall, R. (2015), "Illuminating the way: An emergent theory of place-based leadership development”, Unpublished PhD Thesis, Anglia Ruskin University.

Worrall, R. \& Kjaerulf, F. (2019), “Transforming minds, people and places: Leadership coalition building as catalyst for intersectoral collaboratives in urban violence prevention", Aggression and Violent Behaviour, Vol. 27, pp. 282-292.

Yammarino FJ, Salas E, Serban A, Shirreffs K, and Shuffler ML (2012), "Collectivistic leadership approaches: Putting the "we' in leadership science and practice", Industrial and Organizational Psychology, Vol. 4 No. 4, pp. 382-402. 